УДК 616.411-007.61

DOI

\title{
КЛИНИЧЕСКИЕ СЛУЧАИ СЕМЕЙНОЙ ФОРМЫ БОЛЕЗНИ ГОШЕ І ТИПА
}

\section{CLINICAL CASES OF THE FAMILIAL FORM OF GAUCHER DISEASE TYPE I}

\author{
Н.В. Куркина ${ }^{1,2}$, А.А. Вишнякова ${ }^{1}$ \\ N.V. Kurkina ${ }^{1,2}$, A.A. Vishnyakova ${ }^{1}$ \\ ${ }^{1}$ Национальный исследовательский Мордовский государственный университет имени Н.П. Огарева, \\ Россия, 430032, г. Саранск, ул. Ульянова, д. 26а \\ ${ }^{2}$ ГБУЗ РМ «Республиканская клиническая больница № 4», \\ Россия, 430032, г. Саранск, ул. Ульянова, д. 32 \\ ${ }^{1}$ National Research Ogarev Mordovia State University, 26a Ulyanov St, Saransk, 430032, Russia \\ ${ }^{2}$ Republican Clinical Hospital № 4, 32 Ulyanov St, Saransk, 430032, Russia \\ E-mail: nadya.kurckina@yandex.ru,vishnyackowalina@yandex.ru
}

\begin{abstract}
Аннотация
Болезнь Гоше - это лизосомная болезнь накопления с аутосомно-рецессивным типом наследования. К развитию заболевания приводят мутации гена глюкоцереброзидазы, что проявляется кумуляцией в цитоплазме макрофагов липидов и появлению «клеток Гоше». Накопление нерасщепленных продуктов обмена веществ в цитоплазме макрофагов способствует продукции провоспалительных цитокинов, аутокринной стимуляцией моноцитопоэза и увеличению числа макрофагов в селезенке, печени, легких, костном мозге. Это приводит к нарушению множественных функций этих клеток, а также расстройствам регуляции гемопоэза и обмена веществ костной ткани, что лежит в основе цитопенического синдрома и поражения костно-суставной системы. Рассмотрен клинический случай выявления болезни Гоше I типа у близких родственников - родных сестер на основании гепатоспленомегалии, иммунной цитопении, специфического поражения костно-суставной системы и результатов энзимодиагностики. На фоне проводимой заместительной ферментной терапии (ЗФТ) имиглюцеразой отмечается стабильное течение заболевания без признаков прогрессии. Применение рекомбинантной ГЦБ для ЗФТ характеризуется хорошей переносимостью и отсутствием токсичности.
\end{abstract}

\begin{abstract}
Gaucher disease is a lysosomal disease of accumulation with an autosomal recessive type of inheritance. Mutations of the glucocerebrosidase gene lead to the development of the disease, which is manifested by the cumulative in the cytoplasm of macrophages of lipids and the appearance of «Gaucher cells». Accumulation of non-cleaved metabolic products in the cytoplasm of macrophages, contributes the production of these cells pro-inflammatory cytokines, autocrin stimulation of monocytopoesis and increase the number of macrophages in the spleen, liver, lungs, bone marrow. This leads to the violation of multiple functions of these cells, as well as disorders of the regulation of hemopoesis and metabolism of bone tissue, which is the basis of cytopenic syndrome and damage to the bone-joint system.

A clinical case of Gaucher disease type I detection in close relatives - sisters on the basis of hepatosplenomegaly, immune cytopenia, specific damage to the bone-joint system and results of enzyme diagnosis is considered. Against the background of enzyme replacement therapy (ERT) with imiglucerase there is a stable course of the disease without signs of progression. The use of recombinant drugs for ERT is characterized by good tolerability and lack of toxicity.
\end{abstract}

Ключевые слова: болезнь Гоше, ферментопатия, глюкоцереброзидаза, заместительная ферментная терапия, спленомегалия.

Keywords: GaucherDisease, enzymopathy, glucocerebrosidase, enzyme replacement therapy, splenomegaly. 


\section{Введение}

Болезнь Гоше (БГ) - это наследственная ферментопатия из группы лизосомных болезней накопления. К развитию заболевания приводит наследственный дефицит активности кислой $\beta$-глюкозидазы (глюкоцереброзидазы (ГЦБ)) - лизосомного фермента, участвующего в распаде продуктов клеточного обмена веществ [Воробьев, 2005; Краснопольская, 2005].

Заболевание было впервые описано в 1882 году французским врачом Philippe C.E. Gaucher, выделившим патогномоничные для данной патологии клетки - макрофаги, накапливающие липиды, которые позднее получили название «клетки Гоше». Данное заболевание имеет наследственный характер происхождения с аутосомно-рецессивным типом наследования. В основе заболевания - мутации гена глюкоцереброзидазы, который находится в регионе q21 на 1 хромосоме. К настоящему времени распознано более 200 мутаций, из которых 4 (N370S, L444P, 1448C, 1226G) - наиболее часто встречающиеся и составляющие примерно 90 \% всех мутаций в популяции больных БГ [Лукина и др., 2013]. Существование двух мутационных аллей гена (гомозиготное наследование) связано со снижением (отсутствием) каталитической активности ГЦБ. Это приводит к кумуляции в цитоплазме клеток неутилизированных липидов. Иногда недостаток функции фермента вызван мутацией не гена глюкоцереброзидазы, а гена, который активирует данный фермент - сапозина С.

Накопление в цитоплазме макрофагов нерасщепленных продуктов обмена способствует продукции провоспалительных цитокинов (интерлейкин-1 $\beta$, интерлейкин-6, фактор некроза опухоли $\alpha$ ), а также других маркеров активированных макрофагов (CD14, M-CSF, хитотриозидаза), аутокринной стимуляции моноцитопоэза и увеличению числа макрофагов в селезенке, печени, легких, костном мозге [Лукина, 2014].

Наиболее частой клинической формой болезни Гоше является тип I, который встречается как у детей, так и взрослых. Средний возраст больных в момент манифестации заболевания варьирует от 30 до 40 лет. Болезнь Гоше I типа имеет широкий спектр клинических проявлений: от бессимптомного течения до массивной гепато- и спленомегалии, тяжелых деформаций скелета, значительной анемии и тромбоцитопении, развития тяжелых осложнений [Соловьева и др., 2019]. Поражение костно-суставной системы является одним из основных проявлений заболевания и наблюдается у 70-100 \% больных. Поражение костей при болезни Гоше может носить обратимый и необратимый характер [Соловьева и др., 2019]. Наиболее чувствительным методом диагностики обратимых изменений костной системы при БГ, оценке степени тяжести поражения является магнитнорезонансная томография (MPТ) [Katzetal., 2010; Lukinaetal., 2014].

Основой подтверждения болезни Гоше является энзимодиагностика с определением активности кислой $\beta$-глюкоцереброзидазы в лейкоцитах крови [Лукина и др., 2014]. Дополнительным биохимическим маркером, характерным для БГ, служит существенное повышение активности сывороточной хитотриозидазы - гидролитического фермента, который синтезируется активированными макрофагами. Необходимо учитывать то, что $6 \%$ общей популяции-носители гомозиготной мутации гена хитотриозидазы, и это выражается в отсутствии активности фермента в сыворотке крови [Lukinaetal., 2014].

Цель исследования - представить клинический случай выявления болезни Гоше I типа у близких родственников и оценить эффективность заместительной ферментной терапии (ЗФТ).

Задачи исследования:

1. Выявить особенности клинических проявлений заболевания у пациентов.

2. Проанализировать характерные лабораторно-инструментальные показатели при диагностике болезни Гоше.

3. Оценить эффективность заместительной ферментной терапии. 


\section{Материалы и методы исследования}

Материалы исследования: проводился ретроспективный анализ амбулаторных карт пациенток - родных сестер, у которых подтвержден диагноз болезни Гоше I типа. Рассмотрены особенности клинического течения заболевания, методы лабораторноинструментальной диагностики и результаты заместительной ферментной терапии.

\section{Результаты и их обсуждение}

Под наблюдением гематолога находятся две женщины - родные сестры 70 лет и 59 лет, у которых был подтвержден диагноз Болезни Гоше I типа в 2008 г., после чего назначена заместительная ферментная терапия (ЗФТ).

Клиническое наблюдение 1. Больная Р., 1949 года рождения (70 лет). С 1987 г. отмечались жалобы на боли и тяжесть в правом подреберье, боли в левом подреберье, диспепсические проявления, умеренная интоксикация (слабость, повышенная потливость, утомляемость). При объективном обследовании выявлена гепатомегалия (печень $+8,0$ см из-под края реберной дуги), спленомегалия (селезенка $+6,0$ см из-под края реберной дуги); костносуставная система без видимой патологии. Был диагностирован хронический вирусный гепатит $\mathrm{C}$, минимальная степень активности, по поводу которого она получала консервативную симптоматическую терапию. С 2007 г.: признаки цирроза печени, портальной гипертензии II-III ст., печеночная недостаточность II-III ст., нарастала иммунная цитопения.

Общий анализ крови от 30.10 .2007 г.: Нв - 110г/л, эр - 3,0×10 $12 /$ л, лейк - 3,2×10\% тромб $-50 \times 10^{9} /$ л, СОЭ - $51 \mathrm{мм} /$ ч.

Стали отмечаться проявления специфического поражения костно-суставной системы (структурная перестройка в виде остеопороза метафизарных отделов бедренных, большеберцовых костей; дистальные отделы метафизов бедренных костей умеренно расширены).

Морфологическое исследование костного мозга позволило выявить клетки Гоше (рис. 1).

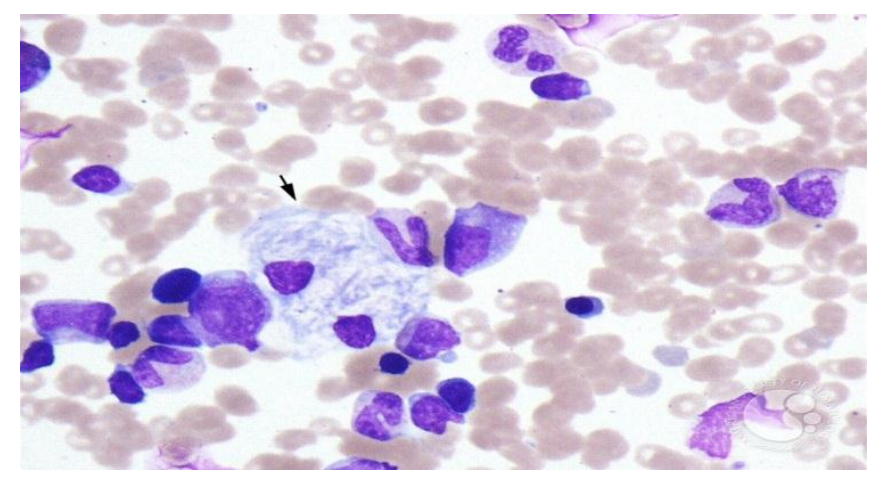

Рис. 1. Пунктат костного мозга с клетками Гоше

Fig. 1. Bone marrow point with Gaucher cells

Диагноз окончательно подтвержден по результатам энзимодиагностики в феврале 2008 г. Цитогенетические маркеры (ПЦР-анализ): в гене наследственного гемохроматоза (HFE) выявлена мутация, приводящая к аминокислотной замене H63D, в одном аллеле (гетерозиготное наследование). Мутаций, приводящих к аминокислотной замене C282Y и S65C, не выявлено. Маркеры тромбофилии (ПЦР-анализ): в генах фактора V, метилентетрагидрофолатредуктазы и протромбина мутаций не выявлено.

Дата начала ЗФТ имиглюцеразой 30 ЕД/кг/введение - сентябрь 2008 г. (2000 ЕД*2 раза в месяц), с 2012 г. - 3200 ЕД/месяц, с 2013г. - 1600 ЕД/месяц, с 2014г. и по настоящее время доза составляет 800 ЕД/введение.

Клиническое наблюдение 2. Пациентка Н., 1960 г. (59 лет). У младшей сестры во время беременности в 1985 году была впервые выявлена гепатоспленомегалия (печень 
$+2,0-3,0$ см из-под края реберной дуги, селезенка $+4,0$ см из-под края реберной дуги), миокардит, которые расценены как картина системной красной волчанки (СКВ), серонегативной формы. Двигательная активность - без ограничений. В течение 1,5 лет получала лечение преднизолоном 60 мг/сут с постепенным снижением дозы. В 1987 году диагноз СКВ был снят, тогда же перенесла острый гепатит А, сопровождавшийся сильными болями в костях с неэффективностью применения НПВС. С этого времени наблюдалась с диагнозом хронического гепатита, с 2007 года - исход в цирроз печени. В феврале 2008 г. в связи с выявлением у родной сестры пациентки болезни Гоше проведен пересмотр мазков костного мозга - обнаружены клетки Гоше.

Диагноз болезни Гоше был верифицирован с помощью энзимодиагностики и ПЦРанализа: в гене наследственного гемохроматоза (HFE) выявлена мутация, приводящая к аминокислотной замене H63D, в одном аллеле (гетерозиготное наследование). Мутаций, приводящих к аминокислотной замене C282Y и S65C, не выявлено. Маркеры тромбофилии (ПЦР-анализ): в генах фактора V, метилентетрагидрофолатредуктазы и протромбина мутаций не выявлено. Гетерозиготная мутация гена PAI-1(4G/5G).

Дата начала ЗФТ - январь 2009 г. (2000 ЕД× 2 раза в месяц), с 2012г. 3200 ЕД/ мес., с 2013 г. - 1600 ЕД/мес., с 2014 г. и по настоящее время доза составляет 800 ЕД/введение.

На фоне проводимой ЗФТ у обеих пациенток отмечается улучшение показателей гемограммы. Показатели красной крови восстановились у обеих пациенток, и в настоящее время проявлений анемического синдрома не отмечается (рис. 2, 3).

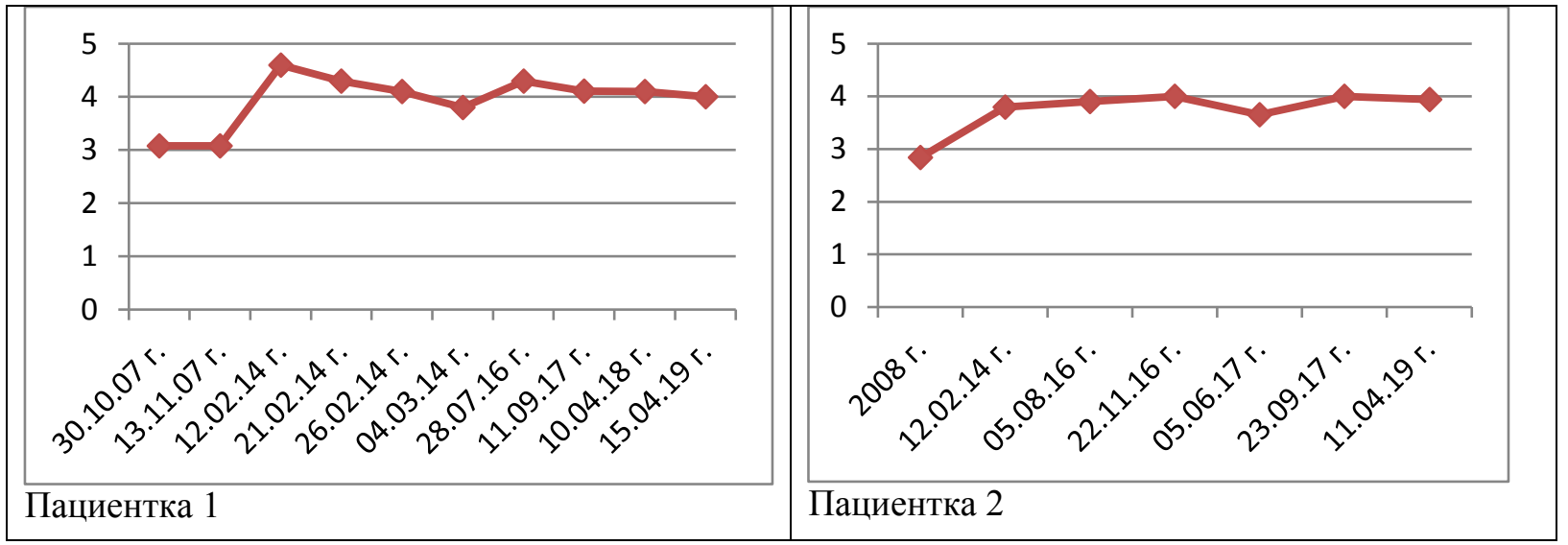

Рис. 2. Динамика показателей эритроцитов на фоне проводимой ЗФТ у пациенток Fig. 2. Dynamics of indicators of red blood cells during ERT in patients

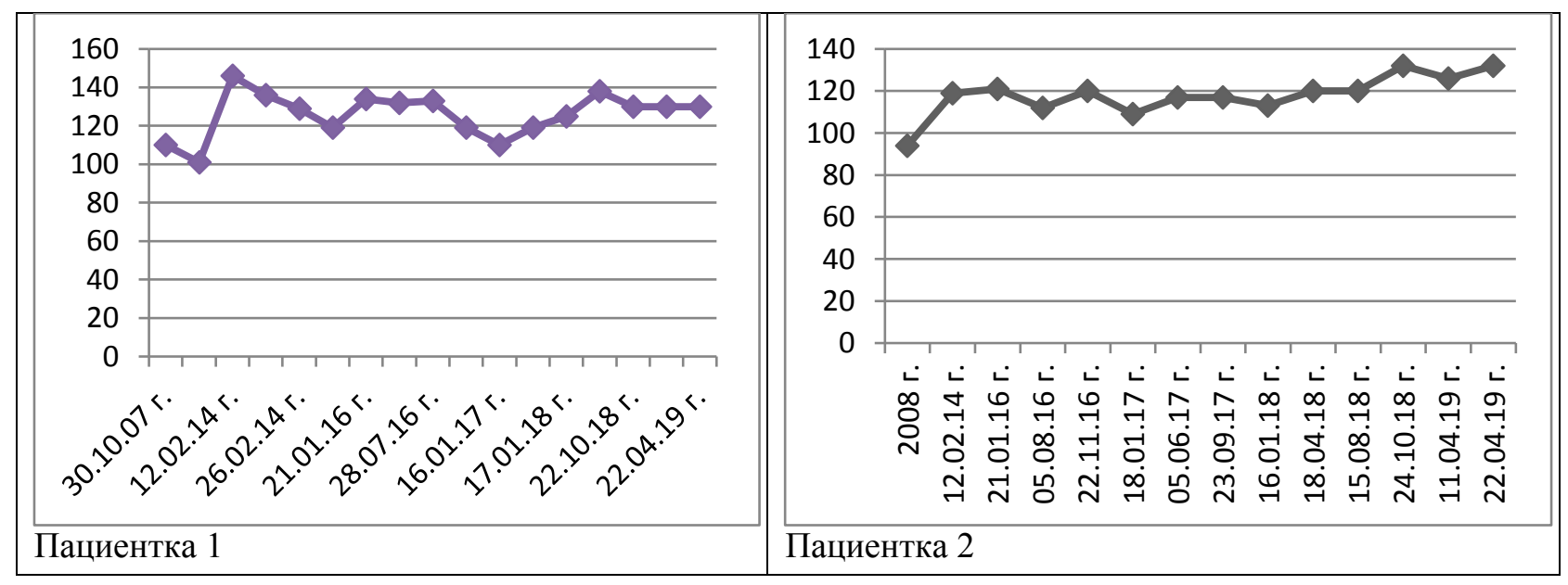

Рис. 3. Динамика уровня гемоглобина на фоне проводимой ЗФТ у пациенток Fig. 3. Dynamics of hemoglobin level during ERT in patients 
Уровень тромбоцитов увеличился до нормальных показателей в среднем через 8 лет от начала терапии, проявлений геморрагического синдрома не отмечалось (рис. 4).

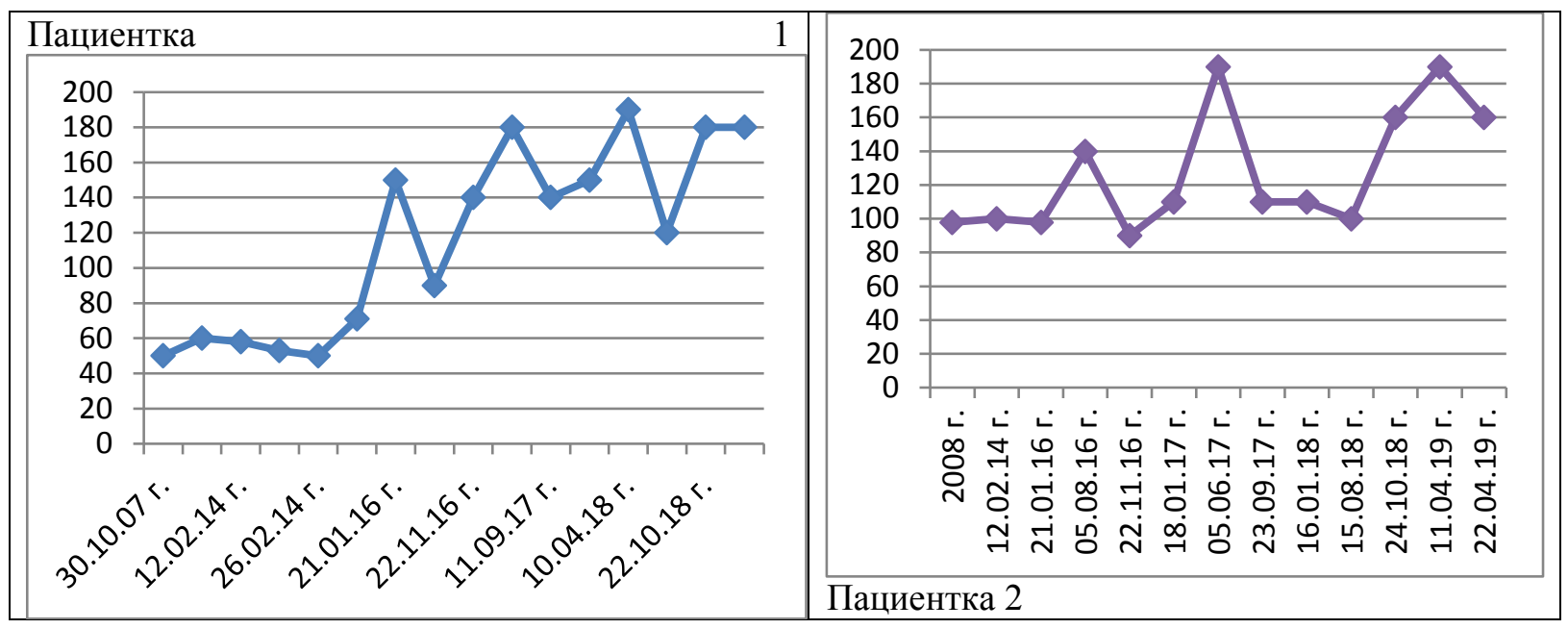

Рис. 4. Динамика показателей тромбоцитов на фоне проводимой ЗФТ у пациенток Fig. 4. Dynamics of platelet indices during ERT in patients

У первой пациентки в дебюте была более выраженная лейкопения, и уровень лейкоцитов восстанавливался медленно (только через 10 лет от начала ЗФТ), а у второй сестры эти показатели достигли нормальных цифр раньше (через 7 лет от начала ЗФТ), причем инфекционных осложнений на фоне проводимой специфической терапии у них не отмечалось (рис. 5).

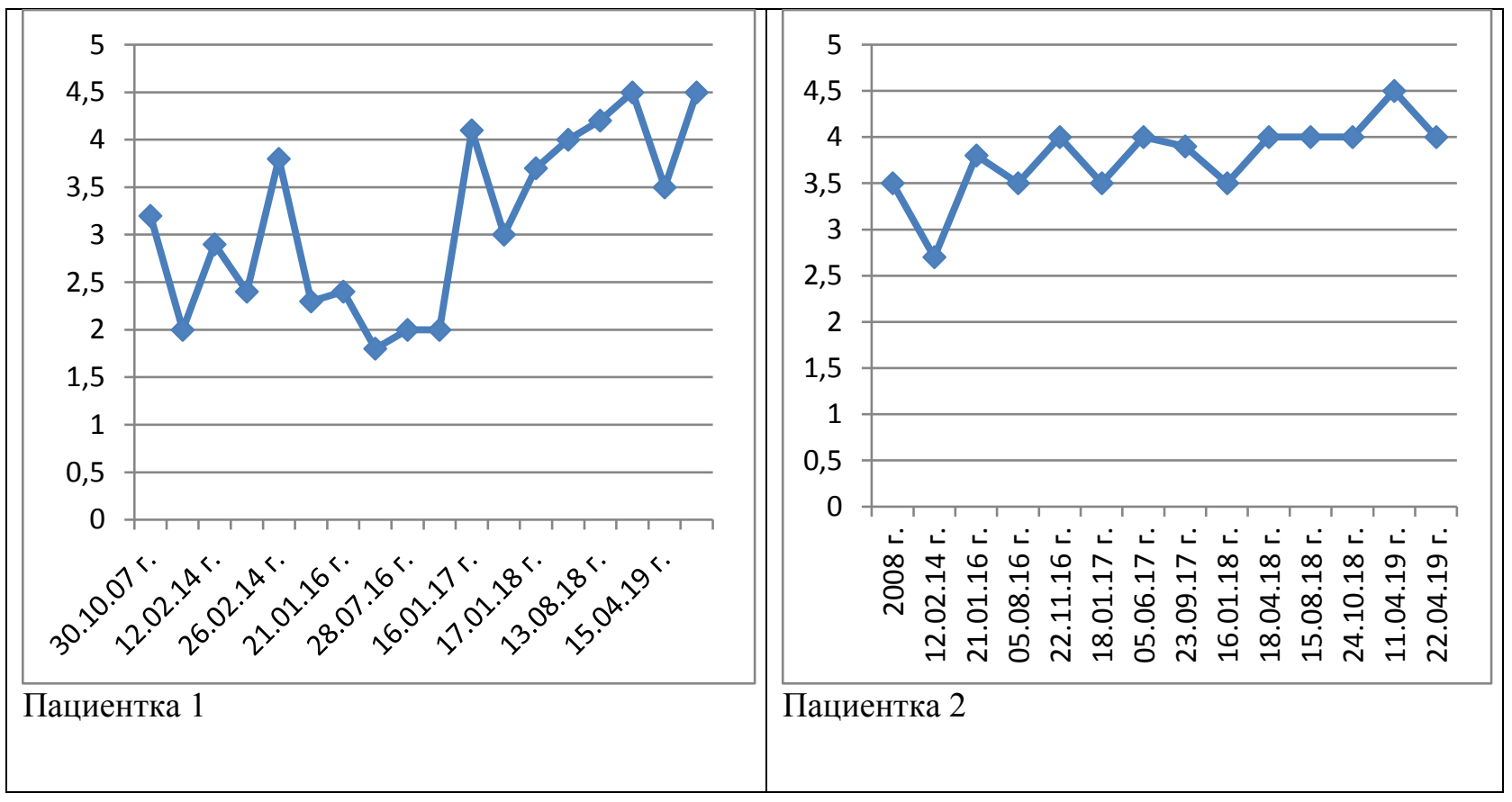

Рис. 5. Динамика показателей лейкоцитов на фоне проводимой ЗФТ у пациенток Fig. 5. Dynamics of leukocytes indices during ERT in patients

Сохраняется умеренное повышение СОЭ (в пределах 20-30 мм/ч), что, возможно, связано с наличием сопутствующей патологии со стороны печени и двустороннего гонартроза с признаками обострения у обеих сестер (рис. 6). 

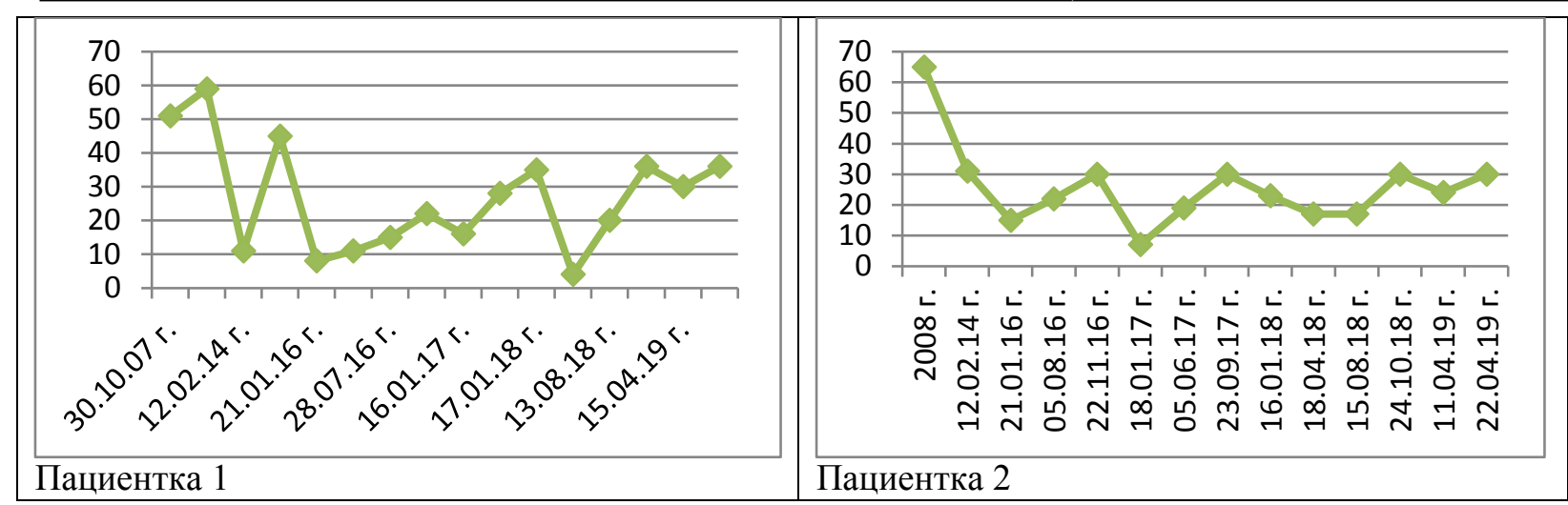

Рис. 6. Динамика показателей СОЭ на фоне проводимой ЗФТ у обеих пациенток Fig. 6. Dynamics of indicators of ESR during ERT in patients

По результатам УЗИ органов брюшной полости в динамике отмечается сохранение гепатомегалии преимущественно за счет правой доли печени (вероятно, обусловлено поражением печени на фоне хронического гепатита) без тенденции к увеличению; размеры левой доли печени у второй пациентки сократились в 2 раза на фоне проводимой ЗФТ (рис. 7).

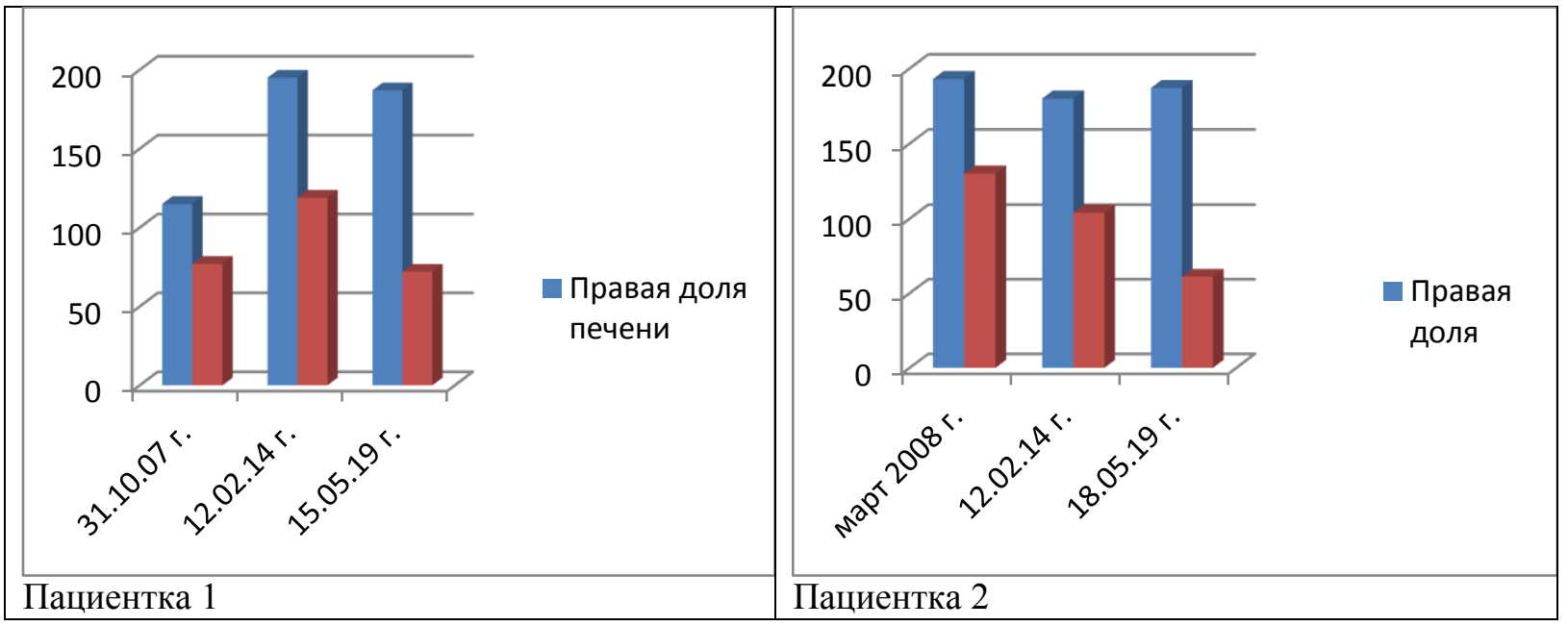

Рис. 7. Размеры печени в динамике на фоне проводимой ЗФТ у пациенток

Fig. 7. Dynamics of liver size during ERT in patients

Размеры селезенки на фоне ЗФТ у первой пациентки сократились в 1,5 раза, однако сохраняется умеренная спленомегалия без признаков гиперспленизма, у второй женщины селезенка сократилась в 4 раза и в настоящее время имеет нормальные размеры (рис. 8).

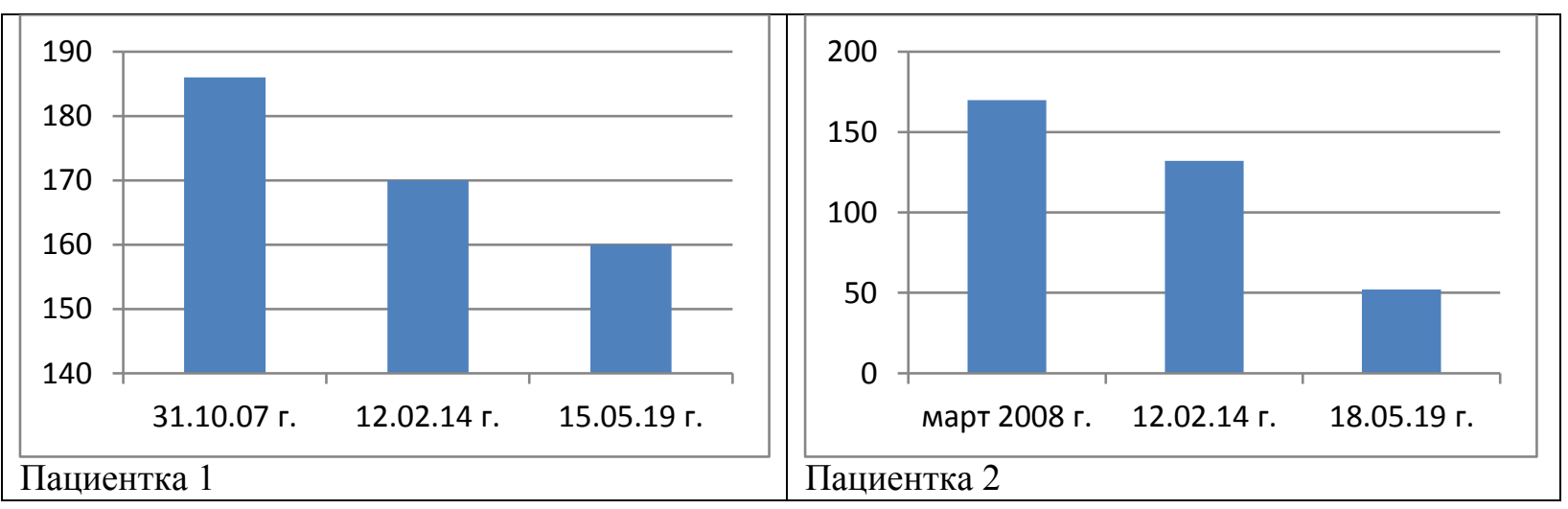

Рис. 8. Размеры селезенки (длинник) в динамике на фоне проводимой ЗФТ у пациенток

Fig. 8. Dynamics of spleen size during ERT in patients 
По результатам рентгенографии и МРТ выявлена картина множественных костнодеструктивных очаговых изменений бедренной, большеберцовой, малоберцовой костей, умеренно выраженные булововидные деформации дистальных отделов обеих бедренных костей (рис. 9), участки разрежения костной ткани с умеренным расширением костномозгового канала на этом уровне; признаки деформирующего остеоартроза коленных суставов с явлениями хондромаляции, дегенеративных изменений менисков, умеренного выпота в суставе. Более выраженные изменения со стороны костной системы отмечались у второй пациентки, вероятно, ввиду раннего дебюта заболевания (с 25-летнего возраста).

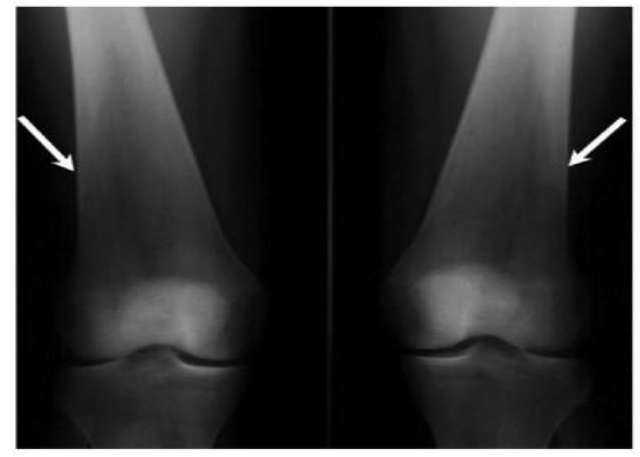

Рис. 9. Рентгенограмма бедренных костей в прямой проекции. Булавовидная деформация дистальных метафизов бедренных костей с расширением костномозговых каналов

Fig. 9. R-graph of femoral bones in direct projection. Mace-like deformity of the distal metaphyses of the femur with expansion of the bone marrow channels

На фоне проводимой ЗФТ структура вещества костного мозга частично восстанавливалась, но преобладали необратимые изменения костно-суставной системы (рис. 10).
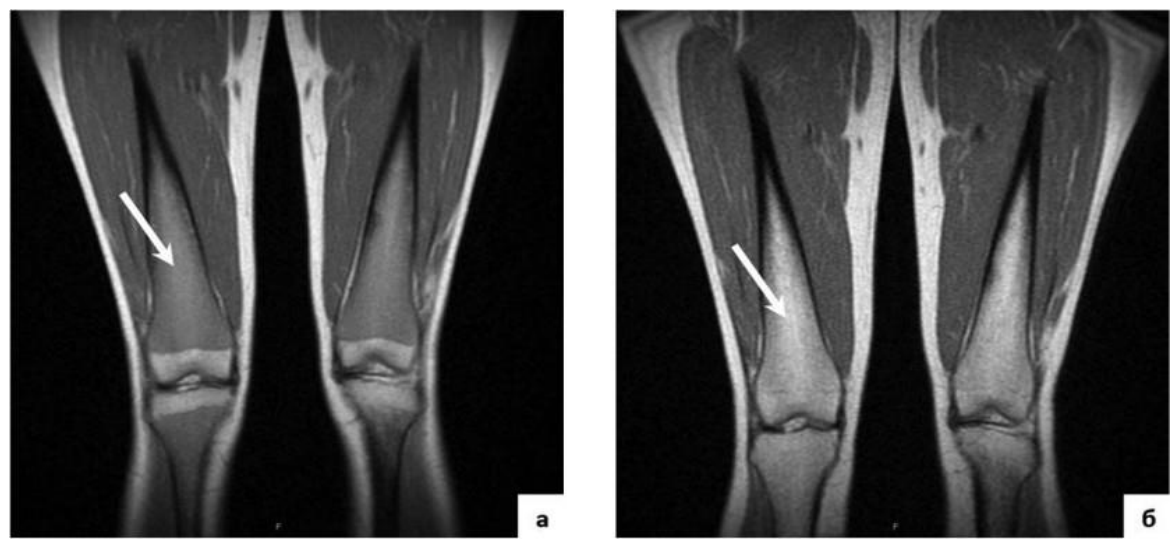

Рис. 10. МРТ бедренных костей с инфильтрацией костного мозга клетками Гоше до лечения (a) и через 7 лет ЗФТ (б)

Fig. 10. MRI of the femur with bone marrow infiltration by Gaucher cells before treatment (a) and after 7 years of ERT (b)

\section{Выводы}

Отмечались определенные трудности при раннем выявлении заболевания у обеих пациенток, так как в дебюте болезни Гоше отмечались неспецифические клинические проявления в виде гепатомегалии и спленомегалии с проявлениями цитопении. Подтверждено гетерозиготное наследование заболевания. Изменения костно-суставной системы имели преимущественно необратимый характер (булововидные деформации дистальных отделов бедренных костей, неоднородность костной структуры с умеренным расширением костномозгового канала). Назначение заместительной ферментной терапии способствует сокращению размеров селезенки, нормализации показателей гемограммы, стабильному течению заболевания, отсутствию прогрессии и осложнений. 


\section{Список литературы}

1. Воробьев А.И. 2005. Руководство по гематологии. М.: Ньюдиамед. Том 2.

2. Лукина Е.А., Сысоева Е.П., Мамонов В.Е., Яцык Г.А., Цветаева Н.В., Гундобина О.С., Финогенова Н.А., Сметанина Н.С., Новиков П.В. 2014. Национальные Клинические рекомендации «Диагностика и лечение болезни Гоше». 13-4.

3. Лукина Е.А. 2014. Болезнь Гоше. М.: Литтера, 56 с.

4. Лукина К.А., Февралева И.С., Сысоева Е.П., Мамонов В.Е., Судариков А.Б., Лукина Е.А. 2013. Характеристика генотипов пациентов с болезнью Гоше I типа в Российской Федерации. Терапевтический архив, 7: 72-75.

5. Краснопольская К.Д. 2005. Наследственные болезни обмена веществ. М.: Медицина.

6. Соловьева А.А., Яцык Г.А., Пономарев Р.В., Лукина К.А., Костина И.Э., Мамонов В.Е., Лукина Е.А. 2019. Обратимые и необратимые изменения костно-суставной системы при болезни Гоше І типа. Гематология и трансфузиология, 64(1): 49-59.

7. Соловьева А.А. 2019. Характеристика и мониторинг изменений костно-суставной системы у взрослых пациентов с болезнью Гоше I типа. Автореферат диссертации на соискание ученой степени кандидата наук. M, 26 c.

8. Lukina K.A., Fevralyeva I.S., Sysoyeva E.P., Sudarikov A.B., Lukina E.A.2014. The molecular genetic diagnostic of gaucher disease type I. Articlein Klinicheskaia laboratornaia diagnostika, 1: 53-55.

9. Katz R., Booth T., Hargunani R., Wylie P. 2010. Radiological aspects of Gaucher disease, 40(12): $1505-1513$.

10. Lukina K., Yatsyk G., Mamonov V., Maksimov A., Sysoeva E., Lukina E. 2014. Radiological assessment of the severity of bone involvement in patients with Gaucher disease. Poster of Congress ECR. C. 2383.

\section{References}

1. Vorob'ev A.I. 2005. Rukovodstvo po gematologii. [Guideto Hematology]. M.: N'yudiamed. Tom 2.

2. Lukina E.A., Sysoeva E.P., Mamonov V.E., Yatsik G.A., Tsvetaeva N.V., Gundobina O.S., Finogenova N.A., Smetanina N.S., Novikov P.V. 2014. Nacional'nye klinicheskierekomendacii «Diagnostika i lechenie bolezni Goshe» [National Clinical recommendations «Diagnosis and treatment of Gaucher disease»]. 13-4.

3. Lukina E.A. 2014. Bolezn' Goshe [Gaucher disease]. M.: Littera, $56 \mathrm{s.}$

4. Lukina K.A., Fevraleva I.S., Sysoeva E.P., Mamonov V.E., Sudarikov A.B., Lukina E.A. 2013. Harakteristika genotipov pacientov s bolezn'y Goshe I tipa v Rossiyskoy Federacii [Characteristics of genotypes of patients with Gaucher I type disease in the Russian Federation]. Terapevticheskiy arhiv. 7: 72-75.

5. Krasnopol'skay K.D. 2005. Nasledstvennye bolezni obmena veshestv [Hereditary metabolic diseases]. M.: Medicina.

6. Solov'eva A.A., Ycyk G.A., Ponomarev R.V., Lukina K.A., Kostina I.E., Mamonov V.E., Lukina E.A. 2019. Obratimye I neobratimye izmeneniya kostno-sustavnoy sistemy pri bolezny Goshe I tipa [Reversible and irreversible changes in the bone and joint system in Gaucher I type I disease]. Gematologiya i transfuziologiya, 64 (1): 49-59.

7. Solov'eva A.A. 2019. Harakteristika I monitorinh izmeneniy kostno-sustavnoy sistemy u vzroslych pacientov s bolezn'y Goshe I tipa [Characteristics and monitoring of changes in the bone and joint system in adult patients with Gaucher I type I disease]. Aftoreferat dissertacii na soiskanie ucheno' stepeni kandidata nauk. M, 26s.

8. Lukina K.A., Fevralyeva I.S., Sysoyeva E.P., Sudarikov A.B., Lukina E.A. 2014. The molecular genetic diagnostic of gaucher disease type I. Article in Klinicheskaialaboratornaiadiagnostika. 1:53-55.

9. Katz R., Booth T., Hargunani R., Wylie P. 2010. Radiological aspects of Gaucher disease, 40 (12): 1505-1513.

10. Lukina K., Yatsyk G., Mamonov V., Maksimov A., Sysoeva E., Lukina E. 2014. Radiological assessment of the severity of bone involvement in patients with Gaucher disease. Poster of Congress ECR.S.2383.

\section{Ссылка для цитирования статьи Reference to article}

Куркина Н.В., Вишнякова А.А. 2020. Клинические случаи семейной формы болезни Гоше I типа. Актуальные проблемы медицины, 43(1): 46-53. DOI

Kurkina N.V., Vishnyakova A.A. 2020. Clinical cases of the familial form of Gaucher disease type I. Challenges in Modern Medicine, 43(1): 46-53 (in Russian). DOI 